\title{
Comparing the Efficacy of Visual Inspection with Acetic Acid and Pap Smear as a Screening tool for Cervical Pre invasive Lesion
}

\author{
Authors \\ Dr Veena Kumari Sinha ${ }^{1}$, Dr Puja Sinha ${ }^{2}$, Dr Abha Rani Sinha ${ }^{3}$ \\ ${ }^{1}$ MBBS, MD, (Obs \& Gynae), FICMCH SKMCH, Assistant Professor, Sri Krishna Medical College, \& \\ Hospital, Muzaffapur, Bihar, India \\ Email:veenasinha01@gmail.com \\ ${ }^{2}$ MBBS, MS (Obs \& Gynae) SKMCH, Senor resident, Sri Krishna Medical College, \& Hospital, \\ Muzaffapur, Bihar, India
}

${ }^{3}$ MBBS, MS Obs \& Gynae) SKMCH, Professor (Obs \& Gynae), Sri Krishna Medical College, \& Hospital, Muzaffapur, Bihar, India

Abstract
Objective: To compare the efficacy of pap smear with VIA (Visual Inspection of Cervix after application of
Acetic acid) as screening of CIN and early cancer cervix.
Material \& Methods: 350 patient who had relevant history and clinical suspicion were subjected to pap
smear, VIA and biopsy. The sensitivity and specificity, false positive rate and false negative rate were
calculated for VIA and Pap smear.
Results: This study showed sensitivity and specificity of pap smear $81 \%$ and $97.8 \%$ respectively and that of
VIA were $86.1 \%$ and $99.1 \%$ respectively.
Conclusion: VIA is a suitable primary screening procedure in developing countries like India as it is
inexpensive, simple and treatment can be administered at the same time.

\section{Introduction}

One of the leading cause of cancer deaths in women is cancer cervix ${ }^{(1)}$ Cancer of cervix is a preventable disease of significant public health concern especially in developing countries.

In India $80-85 \%$ cases are detected late in Stage III or IV $^{(2)}$, Resulting in high motility rates and poor survival.

There has always been a search for a test which would effectively diagnose this disease in early stages. It is seen that every year in India more than $1,20,000$ new cases of Cervical cancer are detected and nearly 75,000 women die annually from disease ${ }^{(3,4,5)}$

\section{Material and Method}

It was a prospective study carried out in outpatient department of Obs \& Gynae in SKMCH, Muzaffarpur between Nov. 2017 and December 2018. 350 patients were enrolled with complaints of blood stained discharge, Post coital bleeding profuse vaginal discharge, intermenstrnal bleeding with a suspicious looking cervix on per speculum examination were included in the study.

Each patient per speculum examination was done and naked eye inspection of cervix was done by VIA with application of $4 \%$ acetic acid. If there was abnormal pap smear finding at least four cervical biopsies (One biopsy each at 2, 4, $8 \& 10^{0}$ 
clock) had been taken out and sent to pathologist suspicious or invisible lesions on VIA were then biopsied. All the specimen which included cytological and histological specimen were analysed by the pathologists and the results were formed and sensitivity and specifically of VIA \& Pap smear were determined.

\section{Results}

Out of 350 patients, ten patients (3\%) did not turn up. In case of VIA, biopsy histology positive (true positive) were 6 cases out of 350 patients. VIA positive cases were 7 cases. Sensitivity \& specificity of VIA calculated were $86.1 \%$ and $99.1 \%$ respectively. In case of pap smear cytology out of 340 patients true positive were 5 patients \& pap smear positive were 7 patients sensitivity \& specificity were $81 \%$ and $97.8 \%$ respectively

Table 1 The result of VIA after application of acetic acid $(\mathrm{N}=350)$

\begin{tabular}{|l|c|c|c|}
\hline & $\begin{array}{c}\text { Biopsy } \\
\text { histology } \\
\text { positive }\end{array}$ & $\begin{array}{c}\text { Biopsy } \\
\text { histology } \\
\text { Negative. }\end{array}$ & Total \\
\hline VIA Positive & 5 & 2 & 7 \\
\hline VIA Negative & 1 & 342 & 342 \\
\hline Total & 6 & 344 & 350 \\
\hline
\end{tabular}

Table 2 The result of pap smear test $(\mathrm{N}=340)$

\begin{tabular}{|l|c|c|c|}
\hline & $\begin{array}{c}\text { Biopsy } \\
\text { histology } \\
\text { positive }\end{array}$ & $\begin{array}{c}\text { Biopsy } \\
\text { histology } \\
\text { Negative. }\end{array}$ & Total \\
\hline Pap smear positive & 4 & 3 & \\
\hline Pap smear Negative & 1 & 335 & \\
\hline Total & 5 & 335 & 340 \\
\hline
\end{tabular}

\section{Conclusion}

Our study showed that the results of VIA is comparable to pap smear and it is safe easy and effective technique and can be a suitable alternative Screening test.

\section{References}

1. WHO (1986) control of cancer of cervix Uteri A WHO meeting Bulletin of WHO 1986 64. 607-18.
2. National cancer Registry programmers consolidated respect of the population based cancer. Registries 2001 - 2004. 71 2.

3. GLOBOCON 2002, Cancer incidence mortality and prevalence in India.

4. Maria ES, Lynne G, Paul DB. Cervical cancer screening in devpping countries. Prim Care updates ob/Gyn. 200; 7:118.2

5. Sankarnarayanan R, Wesley R. Somnath T. Dhakad N, Chandralekha B. Sebasthan $\mathrm{P}$ et al;. Test charactestics of visual inspection with $4 \%$ acetic acid and Lugols iodine in cervical cancer screening in Kerala, India. International Journal of cancer: 2003 Vol 106 page No. 404 - 408.

6. Kumar, Vinay: Abbas, Abdul K; Fausto, Nelson \& Mitchell, Richard N. (2007). Robbins Basic Pathology (8the ed). Saunder Elsevier DP 718 - 721 ISBN978 -14160 - 2973 - 1 .

7. Agorastos T. Miliaras D, L ambropoulos A. Chrisafi S. Kotsis A, Manthos A, Bontis J (2005). Detection and typing of human pappilomavirus DNA in uterine cervices with coexistent grade 1 and grade 3 inpraepitheliae neoplasia; biologic progression or independent lesions? Eur J Obstet Gynecol Reprod Biol 121 (1): 99 103.

8. Goel A, Gandhi G. Visual Inspection of cervix with acetic acid for cervical Intraepithelial lesion Int J Gynecol Obsted 2005; 88:25-30. 